\title{
STRATEGIES FOR MOTIVATING STUDENTS
}

Тьопенко Ю.А

кандидат філологічних .наук, дочент завідувач кафедри іноземних мов

Київський національний університет технологій та дизайну

Motivating students is one of the major challenges teachers face every day. It is really one of the most difficult and the most important aspects of becoming a teacher to learn how to motivate your students. Students who are not motivated will not learn effectively. They will not retain information, they will not participate and some of them may even become disruptive.

There are two basic types of motivation: intrinsic and extrinsic. Intrinsic motivation refers to an inherent interest in pursuing a topic ("learning for learning's sake"). These individuals find a subject enjoyable and they naturally desire to learn mastery of it. Extrinsic motivation, on the other hand, refers to a desire to pursue a subject for reasons outside of the individual, such as rewards, grades, parental or instructor approval, etc. These individuals are motivated to learn a subject not because they want to learn it, but because learning the material will get them good grades, parental praise, or because jobs in that field pay well; all of which are external rewards.

While motivating students can be a difficult task, the rewards are more than worth it. Motivated students are more excited to learn and participate. Simply put: teaching a class full of motivated students is enjoyable for teacher and student alike.

Here are seven effective strategies to develop motivation and get your students excited about learning:

1. Engage and inspire learners by arousing natural curiosity of the topic.

It is no secret that curiosity makes learning more effective and enjoyable. Curious students not only ask questions, but also actively seek out the answers. While it might be no big surprise that we are more likely to remember what we have learned when the subject matter intrigues us, it turns out that curiosity also helps us learn 
information we do not consider all that interesting or important. So if a teacher is able to arouse students' curiosity about something they are naturally motivated to learn, they will be better prepared to learn things that they would normally consider boring or difficult.

2. Use course materials that relate to learners' lives.

Using materials related to learners' lives means students engage with the material, participate in the class, and collaborate with each other. Do not expect your students simply to listen and memorize; instead, have them help demonstrate a process, analyze an argument, or apply a concept to a real-world situation. When you invite students to actively participate in the learning environment, they take more responsibility for their performance in the course. Similarly, when they have an opportunity to make decisions about what they learn and how they use that knowledge, students see a course as more valuable and more directly related to their goals and their lives.

3. Enable students to make connections to others.

While not all students will jump at the chance to work in groups, many will find it fun to try to solve problems, do experiments, and work on projects with other students. The social interaction can get them excited about things in the classroom and students can motivate one another to reach a goal. Teachers need to ensure that groups are balanced and fair, however, so that some students are not doing more work than others.

4. Involve students by giving them the opportunity for self-expression.

Researches show that students engage when they act as their own learning agents working to achieve goals important to them. They must believe they can learn and know how to deal with failures and learn from those experiences. Incorporate problem-solving activities and provide discussions when failures occur. Allow students control over learning. This helps them develop confidence and commitment to learning.

5. Encourage students to be autonomous.

Assigning students classroom jobs is a great way to build a community and to give students a sense of motivation. Most students will see classroom jobs as a 
privilege rather than a burden and will work hard to take turns leading activities or helping out so that each feels important and valued ensure that they, and other students, are meeting expectations. It can also be useful to allow students to.

6. Challenge your students.

If you're not pushing your students to do more than the bare minimum, most won't seek to push themselves on their own. Students like to be challenged and will work to achieve high expectations so long as they believe those goals to be within their reach, so do not be afraid to push students to get more out of them. It can be hard for students to see just how far they've come, especially with subjects that are difficult for them. Tracking can come in handy in the classroom, not only for teachers but also for students. Teachers can use this as a way to motivate students, allowing them to see visually just how much they are learning and improving as the year goes on.

7. Create a positive, fun, relaxed and supportive learning environment.

Avoid monotony by changing around the structure of your class. Teach through games and discussions instead of lectures, encourage students to debate and enrich the subject matter with visual aids, like colorful charts, diagrams and videos. You can even show a movie that effectively illustrates a topic or theme. Your physical classroom should never be boring: use posters, models, student projects and seasonal themes to decorate your classroom, and create a warm, stimulating environment. The aim of the game is success!

For the teacher balancing the pace of a fast moving curriculum with a desire to make learning fun and engaging, perhaps the best motivation system is one that provides both intrinsic and extrinsic motivation. While students may get tangible rewards for their work, they also get positive feedback and chances to explore their own interest within the scope of their subject.

While motivation is often a challenging task for teachers, the rewards of having students who are interested and eager to learn make the hard work worth the effort. By combining intrinsic and extrinsic motivators, teachers can help students learn the subject at hand as well as valuable life skills. 


\section{REFERENCES:}

1. James A. Middleton, "A Study of Intrinsic Motivation in the Mathematics Classroom: A Personal Constructs Approach,” Journal for Research in Mathematics Education, Vol. 26, No. 3, pages 255-257.

2. Ken Bain, What the Best College Teachers Do, Harvard University Press, 2004, pages 32-42.

3. Linda Nilson, Teaching At Its Best: A Research-Based Resource for College Instructors, 2nd edition, Anker Publishing, 2003, pages 41-44.

4. www.edutopia.org/blog/why-curiosity-enhances-learning-mariannestenger

5. Grunert, Judith. The course syllabus: A learning-centered approach. Bolton, MA: Anker Publishing Co, Inc, 1997.

6. Mazur, Eric. Peer instruction: A user's manual. Upper Saddle River: Prentice Hall, 1997. 